\title{
ALESSANDRO MANZONI'S I PROMESSI SPOSI: A CHASTE NOVEL AND AN EROTIC PALIMPSEST
}

In his introduction to I promessi sposi, Manzoni claims to have found in an old manuscript the story he tells in the novel, whereas in fact he has composed it himself. He says he would have loved to copy and publish the original, but modern readers would have found its style intolerable: 'com'è dozzinale! com'è sguaiato! com'è scorretto!' $(P S$, p. 4$) .{ }^{\mathrm{I}}{ }^{\mathrm{H}} \mathrm{He}$ felt sorry that such a beautiful story should remain unknown, and resolved to rewrite it. His is therefore, the subtitle states, a 'storia milanese del secolo XVII scoperta e rifatta'. The first draft dates from 1823 , the first printed version from $\mathrm{I} 827$, and the definitive one from $\mathrm{I} 840$.

A century later, in I930, Guido da Verona published a book entitled in turn I promessi sposi. He tells of being ill in the winter of 1927 during the centennial celebration of the first edition of Manzoni's novel, and of reading it during his convalescence. He uses Manzonian anaphoras to praise it: 'quanto vivi, quanto sinceri, quanto giusti i personaggi'; 'che finezza, che penetrazione, che grande e sincera ondata di bontà umana' ${ }^{2}$ It seems to him, though, that there is something dated in I promessi sposi, and he does to Manzoni's text what Manzoni was simply pretending to do with an original manuscript: he rewrites it and adapts it to contemporary taste.

One of the criteria that inspires his rewriting is brevity: he feels that Manzoni's novel was written 'quando il mezzo di locomozione era la diligenza sgangherata e trabalzante, non le nostre automobili furibonde' (pp. 23-24); so he deletes many episodes, and shortens others. His second innovative criterion is the insertion of sensual and passionate episodes. In his version of the novel, Gertrude does not send innocent love letters to a valet, but seduces the grooms of her paternal home, becoming pregnant at a very young age; Lucia, kidnapped by the Innominato, does not obtain her freedom through pleas, evoking God's name and speeding the process of conversion of her kidnapper, but spends the night with him, tiring him out with her own sexual exuberance. Da Verona's eroticism is vulgar and monotonous, ${ }^{3}$ and the situations of his novel are often repetitive. The introduction to his book, however, is full of intelligent observations, and foreshadows a criticism which from the ig3os on will ever more frequently be made of Manzoni: his excessive modesty; and a question that will

I would like to thank Isabel Marinus, who translated from Italian a first draft of this article, and Ángeles Arce Menéndez, Mark Davie, Danielle Hipkins, Franca Pezzoni, an anonymous referee, and the participants at seminars at the Universidad Complutense in Madrid and the University of Oxford for their helpful comments. This article is part of a larger project supported by an AHRC grant.

All Manzonian quotations come from Alessandro Manzoni, Tutte le opere, ed. by Alberto Chiari and Fausto Ghisalberti, 7 vols (Milan: Mondadori, I 957-91); I indicate I promessi sposi (vol. II, bk I) with the abbreviation $P S$, and Fermo e Lucia (vol. II, bk 3 ) with the abbreviation $F L$.

${ }^{2}$ Guido da Verona, I promessi sposi (Milan: La vita felice, I 998), p. 22.

3 'Lucia Mondella dev'essere stata un bel fiore di contadinotta: noi lo crediamo volentieri. Con una mossa delle sue anche da montanara, con quel po' po' di ben di Dio che certo aveva nel farsetto, con quella sua carne fragrante di selvatichezza e la sua chioma scura ben spartita su la fronte, può aver dato l'uzzolo di volerla tutta per sé a quel ribaldo sterminator di ancelle che doveva essere, col suo pizzo alla moschettiera e la sua tracotante albagia spagnolesca, il signor don Rodrigo' (p. 26).

Modern Language Review, I03 (2008), 424-37

(C) Modern Humanities Research Association 2008 
be asked of I promessi sposi with growing urgency: why does the author keep a deliberate silence on most expressions of love? ${ }^{4}$

In the following pages I analyse the reasons Manzoni has given for his silence, focus on the twentieth-century writers and critics who have repeatedly introduced erotic elements in their rewriting or rereading of I promessi sposi, aiming to understand their reasons (which are often satirical and polemical, but derive in some cases from having glimpsed in the novel what Manzoni had wished to remove from it), and finally discuss the significance which those additions and glimpses might have had. ${ }^{5}$ I have two main objectives: to show the existence of an important interpretative pattern based on an eroticization of Manzoni's novel and linked to significant cultural changes taking place in twentieth-century Italy; ${ }^{6}$ and to highlight Manzoni's awareness of the ways in which readers would react to some of his most radical choices.

Manzoni's resolute avoidance of love scenes in I promessi sposi can be partially explained by the historical context of his literary activity: in the first half of the nineteenth century (and also later) there was a widespread opinion that novels could have a detrimental effect on the morals of their readers, in particular the young and women; ${ }^{7}$ the authors who, like Manzoni, attempted to inspire 'un sentimento [. . .] di simpatia e di rispetto per tutto ciò che è pio, nobile, umano, giusto' $(F L$, p. 8), took great caution in representing feelings and sensations which the reader might then relive with excessive intensity. Manzoni, however, did not submit passively to a convention of his time. He made it his own, by reflecting on seventeenth-century texts and by modifying the conclusions that these reflections usually reached: he did not reject the genre of the novel, as conservative critics did; and he did not try to find a balance between freedom to speak of love and consideration of the mores of the period, as the moderately

4 Da Verona's book is not the first parody of Manzoni's novel: the preceding ones had, however, a different and fundamentally ideological character; in this regard see Manzoni pro e contro, ed. by Giancarlo Vigorelli, 3 vols (Milan: Istituto propaganda libraria, I 975-76), III: Novecento II, pp. 308-i 6 and 734-39.

5 The recreations and reinterpretations of I promessi sposi that I analyse are all the work of male readers: women have addressed Manzoni's work (and life) in other ways, critiquing, above all, the role Lucia plays in his novel, and the roles women played in his family (and in nineteenth-century social structures). For more details, see L. Parisi, 'Come abbiamo letto Manzoni: Anna Banti', Cenobio, $5_{2}$ (2003), 5-16.

6 Interpretative patterns of Manzoni's work have generally been studied in relation to political ideas, mainly Marxist (see e.g. Gianni Scalia, 'Manzoni a sinistra', Italianistica, 2 ( I 973), 2 I-42, and Robert S. Dombroski, 'Manzoni on the Italian Left', Annali d'Italianistica, 3 ( I $^{8} 5$ ), 97I I o) or liberal (the Omodeo-Codignola-Ruffini-Piovani line). Such an ideological approach to the reactions of Manzonian readers has led to interesting results, but it has sometimes had a rather limited scope, and it should at least be integrated with new and different approaches such as the one proposed in this paper.

7 In this regard, one can profit from reading the documents collected by Kate Flint, The Woman Reader I837-I9I4 (Oxford: Oxford University Press, I 993), and, as far as Italy is concerned, by Salvatore S. Nigro, Manzoni (Bari: Laterza, I 978); Ann Caesar, 'Women Readers and the Novel in Nineteenth-Century Italy', Italian Studies, 56 (2001), 80-97, and 'Bagatelle, Bamboccerie, and Bordellerie: The Critics and the Novel in Eighteenth-Century Italy', Italian Studies, 6o (2005), 80-97; and Fabio Danelon, "Se ve l'avessi a raccontare, vi seccherebbe a morte": $I$ promessi sposi, Alessandro Manzoni, il matrimonio', Nuova rivista di letteratura italiana, 5 (2002), $227-85$. 


\section{6 'I promessi sposi': A Chaste Novel and an Erotic Palimpsest}

progressive Pellico suggested. ${ }^{8} \mathrm{He}$ was instead convinced that a novel could be successful even if its author concentrated on themes other than love.

In a digression at the beginning of the second part of Fermo e Lucia, the first draft of the novel, Manzoni imagines a reader turning to him in protest: the leading characters of the story are in love, ready to marry, violently separated by circumstances; their passion goes through stages which should afford ways to express itself, and to develop in a most interesting fashion; and instead, nothing is seen of all this in the novel; this story of yours, the reader objects, 'non ricorda nulla di quello che gl'infelici giovani hanno sentito, non descrive i principj, gli aumenti, le comunicazioni del loro affetto, insomma non li dimostra innamorati' ( $F L$, p. I 43). Manzoni explains that the story found in the manuscript overflows with these things ( $F L$, p. I45), but that he, in transcribing it, skipped over all the passages containing them: he is, in fact, 'del parer di coloro i quali dicono che non si deve scrivere d'amore in modo da far consentire l'animo di chi legge a questa passione' ( $F L$, p. I 44 ). This omission is partly fictional (there is no original manuscript from which some sentimental passages can be omitted) and partly a real act of self-censorship (Manzoni had previously written about love and has decided to stop). ${ }^{9}$

In a later passage, Manzoni refers once again to authoritative figures that have inspired his choice; religion, he says, has had profound thinkers, and sedate reasoners of scrupulous accuracy, who have all disapproved of works in which love is treated in the way his imaginary reader would like ( $F L$, pp. I4546). Manzoni is referring to the French Catholic authors of the second half of the seventeenth century whose books he read at the time of his conversion. His digression follows some of Bossuet's arguments very closely. In Bossuet's opinion, writers 'tendent directement à allumer de telles flammes, qui excitent la jeunesse à aimer, comme si elle n'était pas assez insensée'; ${ }^{10}$ love in this world, writes Manzoni, 've n'ha quanto basta, e non fa mestieri che altri si dia la briga di coltivarlo' ( $F L$, p. I 45$)$. The pleasures of the senses, writes Bossuet,

languissent dans un âge plus avancé, dans une vie plus sérieuse; si ce n'est qu'on se

${ }^{8}$ On 7 January I8 89 Silvio Pellico wrote in Il conciliatore: 'l'Italia può anche desiderare d'acquistare un genere di letteratura [il romanzo] di cui è povera, e permettere che come Petrarca e Metastasio in versi, così altri in prosa si prenda la libertà di commuoverci parlando d'amore senza offendere i costumi. Gli uomini gravi hanno un bel dire; ma vi sono molte passioni più vergognose e meno importanti dell'amore, e questa esercita un troppo grande impero nella società perché non meriti d'essere fatta studio degli osservatori. Pochi uomini sono abbastanza perfetti per essere chiamati al celibato, e per tutti gli altri l'amore è niente meno che l'artefice della felicità o dell'infelicità della loro vita' (quoted by Nigro, p. I28). It is interesting to note that novelists generally associated with Manzoni (D’Azeglio, Grossi, Nievo) are interested in the representation of love (albeit in a non-physical way) and, at least in this case, they are closer to Pellico's position than to Manzoni's.

9 Before writing I promessisposi, Manzoni had described in great detail the throes of love suffered by Ermengarda, the Longobard princess married to Charlemagne, in Adelchi. See, in particular, the chorus of the fourth act, Tutte le opere, I, 625-28.

10 Jacques-Bénigne Bossuet, Maximes et réflexions sur la comédie, in L'Église et le théâtre, ed by C. Urbain and E. Lévêsque (Paris: Grasset, I930), pp. I67-276 (p. I 79), henceforward referred to as $M R$. On the French authors who influenced Manzoni in his decision not to speak of love, see Giovanni Getto, Manzoni europeo (Milan: Mursia, I97I), pp. 59-78. On the more complex influence of Racine, see, in addition to Getto, Gianfranco Contini, 'Manzoni contro Racine', in Esercizi di lettura (Turin: Einaudi, I974), pp. 349-57, and Clara Leri, Manzoni e la 'littérature universelle' (Milan: Centro nazionale di studi manzoniani, 2002). 
transporte par un souvenir agréable dans ses jeunes ans, les plus beaux de la vie humaine à ne consulter que les sens, et qu'on réveille l'ardeur qui n'est jamais tout à fait éteinte. (MR, p. I79)

\section{Manzoni gives the example}

d'una vergine non più acerba, più saggia che avvenente (non mi direte che non ve n'abbia), e di anguste fortune, la quale perduto già ogni pensiero di nozze, se ne va campucchiando, quietamente, e cerca di tenere occupato il cuor suo coll'idea dei suoi doveri [. . .]; ditemi un po' che bell'acconcio potrebbe fare a questa creatura una storia che le venisse a rimescolare in cuore quei sentimenti, che molto saggiamente ella vi ha sopiti. (FL, p. I 44)

Manzoni does not share all the theses of the seventeenth-century authors who systematically censor novels and theatrical performances. ${ }^{\text {II }} \mathrm{He}$ writes a novel devoted to an engaged couple, and does not belittle the feelings they have for each other. ${ }^{12}$ Like Bossuet and like Nicole (and also like Rousseau), he maintains that descriptions of love are dangerous, and omits them, but that omission permits him to talk with pride of his own achievement: 'je me suis donné à croire qu'il y a des difficultés de Bossuet, de Nicole, et de Rousseau qu'on peut résoudre, qu'on n'a jamais résolues, et que je résous' ${ }^{13}$ A novel without passion, for Nicole, is not possible: 'le silence, la patience, la modération, la sagesse, la pauvreté, la pénitence ne sont pas des vertus, dont la représentation puisse

II Theatre, says Bossuet, corrupts the human heart, instilling the passions in the spectator's soul and making them seem more pleasing than they really are $(M R$, p. I 83$)$; novelists, claims Nicole for the same reason, are 'empoisonneurs publics'. The remark by Nicole- to which Manzoni refers explicitly in a letter to Eustachio Degola, I 5 May i 825 (Tutte le opere, viI. I, 377)-comes from Les Visionnaires ('un faiseur de romans et un poète de théâtre est un empoisonneur public, non des corps, mais des âmes des fidèles, qui se doit regarder comme coupable d'une infinité d'homicides spirituels, ou qu'il a causés en effet, ou qu'il a pu causer par ses écrits pernicieux'), and is quoted by Urbain and Lévêsque (p. I 9).

${ }^{12}$ The silence on love, in Manzoni, does not imply a condemnation of that feeling. When Renzo, in a city stricken by plague, is determined to think of his beloved, and to look for her, Father Cristoforo observes that God 'benedice questa [. . .] perseveranza d'affetto' (PS, p. 6 I 4). Father Cristoforo's remark is even more significant if we think of the long dialogue that precedes it in Fermo e Lucia. Renzo tells of having gone to Milan to see if Lucia " "è viva, se si ricorda di me, se mi vuole ancora ...". "O giovane!" disse il Padre Cristoforo, "e in questi tempi, fra questi oggetti, tu hai potuto, tu puoi ancora occuparti di tali pensieri?" "Ma, caro padre mio . . ." cominciò per rispondere il giovane; e non seppe dir di più; perché sentiva egli bene una grande importanza in quei suoi pensieri; erano per lui un affare molto serio; ma era impacciato a trovar le parole convenienti per esprimere una tale idea ad un vecchio capuccino, che era venuto quivi a vivere, a morire, nel ribrezzo, e nelle fatiche per servire a sconosciuti. Parlar d'amore, accennarlo pure con circolluzioni, addurre l'amore come un motivo importante, come una faccenda, in quel luogo, ad un tal uomo, pareva a Fermo una vergogna; e in fatti però non avrebbe potuto parlar d'altro, perché l'amore era il motivo che l'aveva condotto lì. Ma il buon frate lo cavò tosto d'impaccio, rispondendo per lui. L'interrogazione mista di rimprovero che gli era uscita, non veniva dal fondo della sua mente: erano di quelle parole volgari, che precedono la riflessione' ( $F L$, pp. 63I-32) Manzoni does not even make negative comments about sexual desire, in contrast to Bossuet and Nicole, who speak of its intrinsic negativity: the impure, in their opinion, satisfy their sexual desire sinfully; the married satisfy it virtuously; but the continent, who do not satisfy it at all, are morally superior to both (Bossuet, $M R$, p. i 88).

${ }^{13}$ Letter to Claude Fauriel, I I June I8I7 (Tutte le opere, vir. I, I77). This letter contains Manzoni's reflections against the use of Aristotelian unities in the theatre, and anticipates the writer's answer to the perplexities of Bossuet and of Nicole on the moral harm caused by novels. Rousseau attacks the theatre (in the Lettre à $M$. D'Alembert sur les spectacles) and novels (in the 'Seconde préface' to La Nouvelle Héloïse); his Nouvelle Héloïse is another attempt to write a novel dedicated to virtue and lacking in sensationalism. 


\section{8 'I promessi sposi': A Chaste Novel and an Erotic Palimpsest}

divertir les spectateurs'. ${ }^{14}$ Manzoni, instead, places compassion, kindness to neighbour, gentleness, leniency, self-sacrifice, at the centre of I promessi sposi, convinced that his readers will be interested in these feelings of which, he adds, the world has much more need than it does of love $\left(F L\right.$, p. I 45). ${ }^{15}$

Manzoni dropped his digression on love in the published version of I promessi sposi. Most readers did not need it to understand his position. For a long time, they noted his silence on love without much debate: 'Manzoni avoids love scenes', Chandler has written. ${ }^{16}$ 'Se c'è una regola nel decorso del personaggio di Lucia rispetto agli antecedenti letterari', Ulivi has observed, 'è certamente la scrupolosa riduzione dell'elemento romantico sentimentale.' ${ }^{17}$ Manzoni could have been a poet of passion, Croce has observed, but all his mental and moral habits led to a different starting-point in his imagination. ${ }^{18}$ There has been only some discussion on the effect of that silence: Croce found that it harmed the artistic strength of the novel; ${ }^{19}$ most held the opposite view, saying that it was beneficial, 'disincantando da ogni attributivo facilmente usurabile, da ogni connotato reversibile a un umano facilmente stimolante' ${ }^{20}$

According to the majority of commentators, Manzoni's silence is consistent with the modesty with which the betrothed live their love. Lucia is defensive when questioned by Gertrude on the events that drove her to seek refuge in the convent of Monza, and tries not to answer; in Gertrude's story

c'era tirannia, insidie, patimenti; cose brutte e dolorose, ma che pur si potevan nominare: nella sua c'era mescolato per tutto un sentimento, una parola, che non le pareva possibile di proferire, parlando di sé; e alla quale non avrebbe mai trovato da sostituire una perifrasi che non le paresse sfacciata: l'amore! ( $P S$, p. 3 I 3$)$

When the engaged couple meet again after a long absence, Lucia seems cold:

'Vi saluto: come state?' disse, a occhi bassi, e senza scomporsi. E non trovate che Renzo trovasse quel fare troppo asciutto, e se l'avesse per male. Prese benissimo la cosa per il suo verso; e, come, tra gente educata, si sa far la tara ai complimenti, così lui intendeva bene che quelle parole non esprimevan tutto ciò che passava nel cuore di Lucia. Del resto, era facile accorgersi che aveva due maniere di pronunziarle: una per Renzo, e un'altra per tutta la gente che potesse conoscere. $\left(P S, \text { p. } 65^{6}\right)^{21}$

${ }^{14}$ Urbain and Lévêsque, p. 53. Bossuet's opinion is the same: 'tout le dessein d'un poète, toute la fin de son travail, c'est qu'on soit, comme son héros, épris des belles personnes, que l'on les serve comme des divinités' ( $M R$, p. I 77).

15 The final version of I promessi sposi softens many of the theoretical stances Manzoni sets out with an excess of precision in his first version, but without essentially changing them: on this see Georges Güntert, Manzoni romanziere dalla scrittura ideologica alla rappresentazione poetica (Florence: Cesati, 2000).

${ }^{16}$ Stanley Bernard Chandler, Alessandro Manzoni: The Story of a Spiritual Quest (Edinburgh: Edinburgh University Press, I 974), p. Iоo.

${ }_{17}$ Ferruccio Ulivi, Figure e protagonisti dei Promessi sposi ('Turin: Edizioni Rai, I 967), p. 43.

18 Benedetto Croce, Alessandro Manzoni (Bari: Laterza, I 952), p. 20.

I9 'Il mondo, così vario di colori e di suoni, così strettamente congiunto in tutte le sue parti, così inesauribile e così profondo, si semplifica, per non dire s'impoverisce, in questa visione, e di tutte le innumeri corde dell'anima qui vibra una sola, quella che, per esser sola, dava allo Scalvini l'impressione dell'insistente e dell'uniforme. Il motivo ispiratore del Manzoni sembra essere il motto: Dilexi iustitiam, odivi iniquitatem' (Croce, p. 9).

${ }^{20}$ Ferruccio Ulivi, Manzoni: storia e provvidenza (Rome: Bonacci, I 974), p. I 40.

${ }^{21}$ On the same line as Croce are Giuseppe Citanna, Il romanticismo e la poesia italiana dal Parini al Carducci (Bari: Laterza, I 949), pp. I42-43, and Luigi Russo, 'Commento critico', in A. 
Da Verona's remake took these arguments to their logical conclusion: since love scenes are missing in Manzoni's novel, why not try to add them? For da Verona the experiment was disastrous; his Promessi sposi scandalized many Catholics, and pressured Mussolini (who had just signed a concordat with the Church) to act against him; da Verona suddenly found all kinds of obstacles, was unable to publish his books, fell into poverty, had bouts of depression, and died nine years later, perhaps a suicide..$^{22}$ Making fun of Manzoni, in the I930s, could be dangerous.

The idea of updating I promessi sposi survived. In I 970 Piero Chiara rewrote the novel following the same criteria. His rewriting resembles a screenplay; it is brief, lacks descriptive moments, and brings out 'la carnalità nascosta' of Manzoni's characters with what the editor of the book (published posthumously in I996) defines as 'una gioia un po' ruffianesca'. ${ }^{23}$ The parish priest and his maid are lovers; the betrothed groom is arrested in Milan in a prostitute's house; the betrothed bride goes to bed with her kidnapper, with the local signore, and with her own confessor. Chiara's operation, more than that of da Verona, confirms Carlo Sgorlon's opinion that, when speaking of Manzoni, anticlericalism, iconoclasm, and the Italian taste for desecration immediately break loose. ${ }^{24}$ It would be a mistake, though, to believe that the introduction of an erotic component has only had a superficially desecrating function. It also appears in serious remakes of I promessi sposi.

Sebastiano Vassalli's novel La chimera, published in I990, contains a story parallel to Manzoni's novel: there are similarities in the historical and geographical setting, in the tendency to moral reflection, in the detailed references to laws and customs of the past. ${ }^{25}$ Vassalli resets $I$ promessi sposi in an anticlerical mode; his religious figures represent extreme forms of either laxity or intolerance; and the erotic emphasis of some scenes serves this ideological resetting. Antonia, the protagonist who readily laughs, who dances with soldiers passing by, who falls in love with a vagrant and runs away from home to meet him, spending her nights in his embrace under the foliage of chestnut trees, is seen as a rebel by the parish priest and by the self-righteous people of the town.

Manzoni, I promessi sposi, 2nd revised edn (Florence: La Nuova Italia, I967), p. 697; in line with Ulivi, on the other hand, are, in this case, Attilio Momigliano, Alessandro Manzoni, 3 rd annotated and revised edn (Milan and Messina: Principato, I933), p. 222, Natalino Sapegno, Ritratto di Manzoni e altri saggi (Bari: Laterza, I961), p. I30, Getto, pp. 61-62, and Chandler, p. Iоo.

${ }^{22}$ For a critical reconstruction of these events-which in part weakens the cause-and-effect link between the parody of I promessi sposi and the disfavour into which da Verona fell- see Enrico Tiozzo, 'Una tragica parodia: il rifacimento daveroniano de I promessi sposi di Alessandro Manzoni', Romance Studies, 22 (2004), 63-74.

${ }^{23}$ Ferruccio Parazzoli, 'Introduzione', in Piero Chiara, I promessi sposi (Milan: Mondadori, I 996), pp. vii-xv (p. vii).

${ }_{24}$ Gli scrittori d'oggi e il Manzoni, ed. by Claudio Toscani (Milan: Marzorati, I 977), p. 8г.

${ }_{25}$ On all this see Gian Luigi Beccaria, 'Dalle ceneri della storia', L'indice, I 990.5, I0-I I; Cristina Della Coletta, 'L'altra metà del Seicento: da I promessi sposi di Manzoni a La chimera di Vassalli', Italica, 73 ( I 996), 348-68; Ruth Glynn, Contesting the Monument: The Anti-Illusionist Italian Historical Novel (Leeds: Northern Universities Press, 2005), pp. 8 I-I I ; Verina Jones, 'Intertextual Patterns: I promessi sposi in La chimera', Italian Studies, 47 (I 992), 5 I-67; Anna Laura Lepschy, 'Sebastiano Vassalli, La chimera', Times Literary Supplement, 5-I I October I990, p. Io74; and Lorenzo Mondo, 'Miracolo di strega, Chimera di Vassalli: un Seicento non manzoniano', Tuttolibri, i 7 February i 990 , p. I 6. 


\section{0 'I promessi sposi': A Chaste Novel and an Erotic Palimpsest}

Accused of witchcraft, she is raped in an inquisition cell by her jailers. Vassalli condemns in this way the sexual doctrine of the Church, the repression of sexuality operating during the Counter-Reformation, the fear of sex that Catholics in his opinion have always had and that would bring them to identify women with the Devil. ${ }^{26}$

In Manzoni's Promessi sposi, Renzo slips away from his persecutors and, after a long flight, is able to perform an act of charity. Alluding to the strange ways in which good can come out of evil, he exclaims 'la c'è la Provvidenza!' ( $P S$, p. 30I). Thus he expresses his faith in God who mysteriously rules the world. ${ }^{27}$ La chimera's female protagonist meets in jail an old prostitute who sees things in a different light; poor young girls who have no family can count on only one mainstay in life: 'la sola cosa che vi aiuterà ad affrontare il mondo è quell'affare che avete tra le gambe. Li c'è la Provvidenza, quella vera, l'unica che ci viene in aiuto' (p. 34). With artistic and social commitment and with a taste for the provocative, Vassalli does what da Verona and Chiara had done in an ironic and carefree way: he takes for granted the absence of the erotic component in Manzoni's novel and responds to it.

Manzoni was aware of the parodic and polemical reactions that his choices would provoke. Da Verona plays down the acts of generosity of Manzoni's characters by disclosing a hidden sexual desire in them-but Don Rodrigo himself, in the sixth chapter of I promessi sposi, raises the suspicion that Father Cristoforo's intervention on Lucia's behalf may be dictated by a non-evangelical love: 'non capisco altro se non che ci dev'essere qualche fanciulla che le preme molto', 'questa persona le sta molto a cuore'. ${ }^{28}$ His cousin Attilio builds on the insinuation, observing that Father Cristoforo

'protegge, dirige, che so io? una contadinotta di là: e ha per questa creatura una carità, una carità . . . non dico pelosa, ma una carità molto gelosa, sospettosa, permalosa'. 'Intendo,' disse il conte zio; e sur un certo fondo di goffaggine, dipintogli in viso dalla natura, velato e poi ricoperto, a più mani, di politica, balenò un raggio di malizia. ( $P S$, p. 319$)^{29}$

Vassalli evokes the potential hypocrisy of those who boast of intransigent morals-but Sister Gertrude herself, in the tenth chapter of I promessi sposi, when she is secretly seeing a lover, is very strict with the girls in her charge: 'con che sdegno magistrale le gridava, per ogni piccola scappatella' $(P S$, p. I 85$){ }^{3{ }^{\circ}}$

\footnotetext{
26 Sebastiano Vassalli, La chimera (Turin: Einaudi, I 990), p. 236.

27 'Se a sostenere in quel giorno que' poverini che mancavano sulla strada, la Provvidenza aveva tenuti in serbo proprio gli ultimi quattrini d'un estraneo, fuggitivo, incerto anche lui del come vivrebbe; chi poteva credere che volesse poi lasciare in secco colui del quale s'era servita a ciò, e a cui aveva dato un sentimento così vivo di se stessa, così efficace, così risoluto?' ( $P S$, pp. 30 Io2). According to Ezio Raimondi, Il romanzo senza idillio (Turin: Einaudi, I974), and to many scholars inspired by him, Manzoni's characters have a mechanistic view of Providence which Manzoni would not share. Vassalli follows this interpretation, which I have disputed in 'Manzoni e la modernità: un dialogo con Ezio Raimondi', Forum Italicum, 35 (2001), 332-50.

${ }^{28}$ Father Cristoforo understands the implicit message and counters immediately: 'la mi preme, è vero, ma non più di lei; son due anime che, l'una e l'altra, mi premon più del mio sangue' ( $P S$, p. 90).

${ }_{29}$ Luigi Russo observes that 'per un animo di scapestrato come Attilio, l'interessamento di fra Cristoforo a Lucia non può essere che impuro [. . .] E in quell'intendo si scopre meglio la turpe $\mathrm{e}$ goffa malizia senile del conte' (p. 354).

${ }^{\circ}$ Even the explicit tone of Chiara would not have surprised Manzoni. The city of Milan was
} 
Manzoni, however, could not foresee the reaction of other twentieth-century writers and critics who have resorted to I promessi sposi to speak in their turn of love and passion, not to fill a gap in the novel, but with the conviction of having identified in it a surviving erotic dimension. In the eighth chapter of I promessi sposi, in a passage to which Vassalli alludes (p. 39), and which da Verona repeats to the letter, ${ }^{3 \mathrm{I}}$ Lucia flees during the night from the village to escape the feudal lord who wants her for himself. She will seek refuge in a convent together with her mother; Renzo, the betrothed groom who is with them that evening, will continue his way to Milan. As the boat crosses the lake, Lucia turns her gaze to the places she has always lived in, and is leaving for ever, and says goodbye:

addio, monti sorgenti dall'acque, ed elevati al cielo; cime inuguali, note a chi è cresciuto tra voi, e impresse nella sua mente, non meno che lo sia l'aspetto de' suoi più familiari; torrenti, de' quali distingue lo scroscio, come il suono delle voci domestiche; ville sparse e biancheggianti sul pendìo, come branchi di pecore pascenti; addio! Quanto è tristo il passo di chi, cresciuto tra voi, se ne allontana! [. . . Addio, casa natia, dove, sedendo, con un pensiero occulto, s'imparò a distinguere dal rumore de' passi comuni il rumore d'un passo aspettato con un misterioso timore. Addio, casa ancora straniera, casa sogguardata tante volte alla sfuggita, passando, e non senza rossore; nella quale la mente si figurava un soggiorno tranquillo e perpetuo di sposa. Addio, chiesa, dove l'animo tornò tante volte sereno, cantando le lodi del Signore; dov'era promesso, preparato un rito; dove il sospiro segreto del cuore doveva essere solennemente benedetto, e l'amore venir comandato, e chiamarsi santo; addio! (PS, pp. I43-44)

The young woman is so immersed in her own thoughts that she is unaware of having reached the other side of the lake: 'l'urtar che fece la barca contro la proda, scosse Lucia, la quale, dopo aver asciugate in secreto le lacrime, alzò la testa, come se si svegliasse' ( $P S$, p. I 45).

Alberto Moravia took up this passage in Gli indifferenti, his first novel, written when he was twenty-one and published in $1929 .{ }^{32}$ In the eighth chapter the protagonist leaves her house after midnight, in secret, to join her mother's lover, who has been courting her for some time and who is waiting for her in a car. Carla will spend the night with him, perhaps because she is a virgin and curious about sex, because she hopes to change her own existence and she likes Leo in spite of the difference in age, but also because of an unconscious desire for self-destruction. When the car starts off, Carla says goodbye to the streets and houses in her neighbourhood with words and rhythm similar to those of Manzoni’s Lucia:

an anomaly in prudish nineteenth-century Italy, and a friend of Manzoni's, Carlo Porta, could tell about the sexual awakening of Ninetta del Verzee in abundant detail. On Porta and Manzoni, see Vittorio Spinazzola, Il libro per tutti: saggio sui 'Promessi sposi' (Rome: Editori riuniti, I983), pp. 56-58.

3r Da Verona, however, ironically notes the length of the passage and breaks off the sentences with some etceteras: 'Addio, monti sorgenti dall'acque, ed elevati al cielo; cime inuguali, note a chi . . . eccetera; torrenti de' quali . . . eccetera; ville sparse e biancheggianti sul pendio, come branchi . . . eccetera; addio, casa natia, dove, sedendo, con un pensiero . . eccetera' (p. 95). Manzoni's farewell to the mountains, which has had many imitations in Italy (among them Ippolito Nievo's in Le confessioni di un italiano), was probably inspired by Die Jungfrau von Orleans by Schiller. On this see Getto, Manzoni europeo, pp. 195-99.

${ }^{2}$ On the importance of Gli indifferenti in the history of Italian literature, see in particular Alberto Asor Rosa, 'Centralismo e policentrismo', in Letteratura italiana: storia e geografia, ed. by A. Asor Rosa, 3 vols (Turin: Einaudi, I 989), III, 5-74 (pp. 45-47). 


\section{2 'I promessi sposi': A Chaste Novel and an Erotic Palimpsest}

addio strade, quartiere deserto percorso dalla pioggia come da un esercito, ville addormentate nei loro giardini umidi, lunghi viali alberati, e parchi in tumulto; addio quartiere alto e ricco: immobile al suo posto a fianco di Leo, Carla guardava con istupore la pioggia violenta lacrimare sul parabrise. ${ }^{33}$

Carla is lost in her own reflections and 'quando, dopo dieci minuti, l'automobile si fermò improvvisamente e questo pensiero le venne: "siamo arrivati”, l'impressione fu tale che il respiro le mancò' (I, I60).

Moravia's references to I promessi sposi are generally polemical, ${ }^{34}$ and an essentially satirical or hostile intention has likewise been seen in this remaking of Lucia's farewell: ${ }^{35}$ the trip of an uninhibited young woman to the house of her lover is told with the words which Manzoni uses, instead, to express the thoughts of a virtuous nineteenth-century country girl fleeing from an oppressor. This passage, however, has a much deeper significance. Moravia often describes the drama of adolescents betrayed by adults: Girolamo in Inverno di malato is stalked by an older patient, who, taunting him for his sexual inexperience, forces him into 'una nera atmosfera di umiliazione e di sofferenza' (I, 368); Andreina in Le ambizioni sbagliate is seduced at fourteen by an older tenant in her paternal home, and she remains fatally fond of him; mothers, through vanity or greed, lead the young protagonists of La provinciale and La romana astray. In all these stories-as if a recurring situation in Moravia's narrative had a mysteriously close link to Manzoni's page - the echoes of Lucia's farewell continue to appear. Girolamo is immersed in sad thoughts, and 'l'urtar che fece il letto contro lo stipite della porta della sua stanza lo destò da queste amare riflessioni' ( $(, 383$ ). The protagonist of La romana says goodbye to her youth in a nocturnal trip which, once again at the end of the eighth chapter, ends with a sudden shock (II, 8०3-04). The protagonist of La provinciale abandons

33 Alberto Moravia, Opere, three volumes published, others forthcoming (Milan: Bompiani, 2000- ), I, I 60 . All the following quotations by Moravia come from this edition.

34 The protagonist in La romana makes a vow similar to that of Manzoni's Lucia, but her prayer is not answered (II, I 066-69); the protagonist of a story falls asleep upon reading I promessi sposi because 'le prediche talvolta fanno venir sonno' (I, I 4 I 3-I 4); the characters of another of Moravia's stories appear, like a famous Manzonian figure (PS, p. 596), 'dalla soglia di una di queste porte' (II, 588), but they turn out to be hopelessly mean-spirited. In La Ciociara, Moravia carries out a deliberate anti-Manzonian diminutio: see Gian Paolo Biasin, 'Lucia according to Moravia', Il Verri, I I (1975), 56-68 (p. 64). A r 960 essay by Moravia ('Introduzione' to A. Manzoni, I promessi sposi (Turin: Einaudi, I 960), now available in A. Moravia, L'uomo come fine e altri saggi (Milan: Bompiani, I 963)) scandalized Manzonians by claiming that I promessi sposi describes a morally degraded world, and that its author takes pleasure in such degradation. In disagreement with this thesis are scholars as diverse as Cesare Angelini, Capitoli sul Manzoni, vecchi e nuovi (Milan: Mondadori, r 966), pp. 308-i 2; Alberto Asor Rosa, 'Recensione' of the Einaudi edition and of A. Manzoni, I promessi sposi with an introduction by Natalino Sapegno (Milan: Feltrinelli, I 960), in La rassegna della letteratura italiana, 65 ( I 96 I ), i 1 9-33; Carlo Emilio Gadda, 'Manzoni diviso in tre dal bisturi di Moravia', Il giorno, 26 July r96o, p. 6; Enzo Noè Girardi, Manzoni 'reazionario' (Rocca San Casciano: Cappelli, i 966), pp. 63-84; Edoardo Sanguineti, Tra Liberty e crepuscolarismo (Milan: Mursia, I965), pp. 20I-I 5, and Ulivi, Manzoni: storia e provvidenza, pp. I7, 92, and 243-44. In partial defence of Moravia, Giorgio Pullini, 'Moravia saggista e la poetica del realismo', Comunità, 3 I (I 977), 342-89, said that his literary essays 'sono da leggersi più in funzione della poetica dello stesso Moravia che come saggi critici autonomi’ (p. 372).

35 This interpretation is, for example, in Alberto Limentani, Alberto Moravia fra esistenza e realtà (Venice: Neri Pozza, I 962), pp. 22-23; Paolo Valesio, 'La riscrittura come scrittura degradata: un caso novecentista', in Miscellanea in onore di Luigi Heilmann per il $75^{\circ}$ compleanno (Bologna: CLUEB, I987), pp. 635-5I (p. 647); and Valentina Mascaretti, La speranza violenta: Alberto Moravia e il romanzo di formazione (Bologna: Gedit, 2006), p. I 38 . 
her native city and says goodbye to its various parts, carefully looking at them for the last time (I, I $090-9$ I).

Carla, the protagonist of Gli indifferenti, has adolescent traits (her bedroom is full of stuffed animals), is naive (for a lover she picks a much older and selfish man who will humiliate her and stifle for ever her desire for change), and finds herself in an extremely delicate moment of her existence. The uncertainties of Manzoni's protagonist, her concerns, the sense of mystery that the future brings with it in the night of her flight, are also true for her. There is, on the other hand, an unconscious foreshadowing of Carla in the heroine of I promessi sposi, who travels for the first time in her life in the company of a man, in what should have been the first night after their wedding, pursued by a man who wants her for himself. ${ }^{36}$ Manzoni barely alludes to the sexual implications of the situation by pointing to the 'casa ancora straniera [. . .] sogguardata tante volte alla sfuggita, passando, e non senza rossore'. Moravia's reference to I promessi sposi, revealing the parallelisms between the two stories, enriches both with a sensitivity that the seeming polemical irreverence tries to hide, but which it ultimately accentuates. ${ }^{37}$

An important reference to I promessisposi can also be found in Mario Soldati's La confessione, a novel with autobiographical overtones,,$^{38}$ begun in the I93os, completed twenty years later, and first published in i 955 . Clemente, neglected by his parents, is raised by a self-righteous aunt who would make a priest of him, and by a group of Jesuits who insistently warn him against sexual temptations and present women as instruments of the Devil. Clemente does not know how to behave: he avoids women, but is attracted to them. He feels above all the fascination of a friend of his mother's, Jeannette, who every once in a while accompanies him to the beach. The way she moves, her laugh, her gaze, her words, their occasional contact disturb him. The woman invites him one evening to her hotel room and makes it clear to him that she is willing to make love: Clemente finds himself suspended in an anguished uncertainty; the mysterious and unmistakable voice of nature invites him to enter, it tells him that sin and the Devil have nothing to do with Jeannette;"39 and yet, 'come poteva, povero ragazzo, fidarsi soltanto della voce della natura, così sommessa, e d'un tratto non credere più in ciò che dalla primissima infanzia madre, nonna, monache, preti, padri e maestri gli avevano quotidianamente, massicciamente inculcato?' (pp. I46-47). He bursts into lacerating sobs and flees.

Clemente shares several characteristics with Gertrude, the young aristocrat forced to become a nun in Manzoni's I promessi sposi. He is worn down as she is by psychological pressures exerted by his family: like her, he loves his parents and would like to please them; like her, he boasts every now and then of the

\footnotetext{
${ }^{36}$ Mario Soldati, Rami secchi (Milan: Rizzoli, r 989), understands the similarity of the two stories, although he harps excessively on it (p. 52).

37 It must be noted that Carla, for just an instant, has the positive moral effect that Lucia has on the people around her: alone with her 'per la prima volta da quando Carla lo conosceva, Leo ebbe un riso fresco, quasi giovane, spontaneo' (I, I 70).

${ }_{38}$ The subject in La confessione is 'il ragazzo Soldati' according to the writer, as reported by Davide Lajolo, Conversazione in una stanza chiusa con Mario Soldati (Milan: Frassinelli, I983), p. 19

${ }^{39}$ Mario Soldati, La confessione (Milan: Mondadori, I 959), p. I 46.
} 


\section{4 'I promessi sposi': A Chaste Novel and an Erotic Palimpsest}

ecclesiastical future for which he is destined and discovers to his amazement that his peers do not find that future attractive and scoff at it. Above all, like Manzoni's Gertrude, Clemente is not able to take control of his own destiny, and he is swept up by events. ${ }^{40}$ The intertextual references extend the compassion traditionally felt for Gertrude to Clemente, on the one hand, and, on the other, give new evidence of the erotic component which-upon careful examinationone can see in Gertrude's story. As a child she is full of confused yet welcome images of a future life in marriage $(P S$, p. I 54). As an adolescent, she feels a mysterious power enter her soul, spread like a mist, and predominate in her imagination ( $P S$, pp. I 58-59). On the day of her vows as a novice, she feels great sadness when being called, metaphorically, young bride, 'sposina' ( $P S$, p. I73) ${ }^{4^{\mathrm{I}}}$ As a nun she wearily wanders 'dietro a desideri che non sarebbero mai soddisfatti' $(P S$, p. I 84$) .^{42}$ Soldati's reinterpretation immediately produced imitators: in I 958, without naming him, Jean-François Revel announced he had discovered 'le désir sexuel frustré' at the heart of Gertrude's story. ${ }^{43}$

The recreations and intertextual references that we have considered are obviously examples of the many ways in which a classic work can be revisited: seriously or superficially, ironically, for polemical ends, or on the basis of a revitalizing understanding. They also show important changes that have taken place in twentieth-century culture. In a genuinely liberal society, authors are less cautious in representing feelings and sensations which readers might then relive with excessive intensity; they assume that no authority or institution can shield the individual from dangers which are still perceived as real, ${ }^{44}$ but which must ultimately be overcome at the personal level. ${ }^{45}$ The physical component

\footnotetext{
$4^{\circ}$ Soldati: 'era giunto il momento di essere forte. O forte nel peccato, andando verso Jeannette decisamente e gettandosi ai suoi piedi e baciandoli. O forte nella virtù, rispondendo al sorriso di Jeannette con un sorriso di gentilezza, ringraziandola e augurandole la buona notte. Ma si accorse che non poteva essere forte né in un modo né nell'altro' (p. I45). Manzoni: '-O mi vorranno forzare, - pensava, - e io starò dura; sarò umile, rispettosa, ma non acconsentirò; non si tratta che di non dire un altro sì; e non lo dirò. Ovvero mi prenderanno con le buone; e io sarò più buona di loro; piangerò, pregherò, li moverò a compassione: finalmente non pretendo altro che di non essere sacrificata. - Ma, come accade spesso di simili previdenze, non avvenne né una cosa né l'altra' $(P S$, p. I6 г). Echoes of this passage of Manzoni's are also in Moravia (I, 693, I I 74, and I I 84).

${ }_{41}$ The words the chambermaid addresses to her-'Andiamo, andiamo, signora sposina'-form a hendecasyllable and are as cheerful as the start of a dance song, observes Cesare Angelini, Manzoni (Turin: UTET, I 942), p. I 75.

${ }^{42}$ Gertrude renounces her resistance to the religious life when her father intercepts a letter she has sent to a young man of her own age; and she rebels against her own monastic state by becoming the lover of a man living near the convent. Egidio 'osò rivolgerle il discorso. La sventurata rispose' $(P S$, p. I 86$)$.

43 Jean-Francois Revel, Pour l'Italie (Paris: Juilliard, I958), p. 58. An answer to Revel's considerations, interesting also because of the way in which the theses of the French journalist are reported and his words are muted, is in Vittorio Lugli, Bovary italiane ed altri saggi (Caltanissetta and Rome: Sciascia, I 959), pp. I 35-40.

${ }_{44}$ See e.g. the observations made in 1942 by Albert Camus, Le Mythe de Sisyphe (Paris: Gallimard, 2007), which apply to both plays and novels: 'comment l'Église n'eût-elle pas condamné [...] pareil exercise? Elle répudiait [. . .] la multiplication hérétique des âmes, la débauche d'émotions, la prétention scandaleuse d'un esprit qui se refuse à ne vivre qu'un destin et se précipite dans toutes les intempérances. Elle proscrivait en eux ce gout du présent et ce triomphe de Protée qui sont la négation de tout ce qu'elle enseigne. L'éternité n'est pas un jeu' (p. I I4).

45 Among the many texts dealing with this subject in Italy, Alberto Caracciolo's 'Cultura e libertà', published in 1948 and now collected in A. Caracciolo, Politica ed autobiografia (Brescia:
} Morcelliana, I993), pp. I 49-70, stands out for its timeliness and clarity. 
of love which at first caused embarrassment or was passed over in silence has become an object of explicit discussion, of assertions, of personal and collective liberation. Guido da Verona speaks openly of sex, but from a limited point of view. The characters in Moravia (one of the first Italian novelists to have read Freud) are aware of the critical role erotic impulses play in human life, but are unable to live them in a liberating manner; they would like to 'dimenticare tutto quanto [hanno] appreso, per poi riapprenderlo senza vergogna né offesa' (II, 38I). Soldati states in La confessione the possibility and necessity of a fulfilling sexual experience and argues in favour of this against the continence preached by the Roman Catholic Church. The recent critics I will focus on to conclude, Vittorio Spinazzola and Paolo Valesio, belong to i 980 os Italy, ${ }^{46}$ a secular society that has approved the distribution of the contraceptive pill and the legalization of divorce and abortion, in which few feel the need to engage with the teaching of the Roman Catholic Church. ${ }^{47}$

Spinazzola and Valesio do not take the absence of love in I promessi sposi for granted. For them Manzoni's novel is a place where an attempt at deeroticization has been made,$^{48}$ and where eroticism asserts itself in spite of the author's self-imposed censorship. Lucia, says Spinazzola, has two ways of expressing herself, one verbal and one behavioural: the first is straightforward, but inevitably self-censoring; rising from the second is an affective authenticity, made up of things unspoken and unspeakable, with blushing as its unmistakable sign (Il libro per tutti, p. I22). Lucia remains faithful to Renzo when Donna Prassede tries to distance her from him, and here more than anywhere, Spinazzola observes, the circumlocutory formula used to designate love exalts its irresistible force:

atteggiato nei modi dell'allusione e dell'ellisse, l'amore assume aspetto d'un nodo inviolabile di mistero, in cui si intrecciano intelletto e sentimento, individualità e socialità, infine meccanismo naturalistico e finalismo creativo. Del mistero non si dà esplicazione: lo si conosce solo nella esperienza pratica. (Il libro per tutti, p. 298; see also p. I 29)

Valesio focuses on the separation of Renzo and Lucia in the ninth chapter. It is 'una separazione dolorosa' ( $P S$, p. 202), said with few words which in the first draft brought about the objection of the imaginary reader, and the digression where Manzoni explains the reasons for his personal silence on love. The young man

avrebbe voluto sostare almeno tutta la giornata, ma Agnese e Lucia lo persuasero a partire, ed egli partì, tutto incerto dell'avvenire, ma certo almeno che un cuore rispondeva al suo, e viveva delle sue stesse speranze. ( $F L$, p. I 4I)

Valesio notes that, in the final version of I promessi sposi, Manzoni

\footnotetext{
${ }^{46}$ It must be said, however, that Paolo Valesio, born and raised in Bologna, was at the time a professor of Italian literature at Yale University.

47 On the concept of love which has taken hold in twentieth-century Europe and Italy, see respectively Angus McLaren, Twentieth-Century Sexuality (Oxford: Blackwell, I 999), and Marta Boneschi, Senso: i costumi sessuali degli italiani dal I880 a oggi (Milan: Mondadori, 2000).

${ }^{8}$ Paolo Valesio, 'Lucia, ovvero la "reticentia”', in Leggere i Promessi sposi: analisi semiotiche, ed. by Umberto Eco and others (Milan: Bompiani, I 989), pp. I 45-74 (p. I 57), connects this attempt to the homiletic nature of nineteenth-century Christianity; Spinazzola redirects it rather to the affirmation of a religious, not secular, vision of life (Il libro per tutti, pp. 8-9).
} 


\section{6 'I promessi sposi': A Chaste Novel and an Erotic Palimpsest}

taglia tutta la 'digressione'; ma (qui sta l'interesse) fino a un certo punto accoglie la voce critica di quella parte di sé (il 'personaggio ideale') che aveva trovato la scena della separazione troppo 'secca, digiuna, concisa'-e riscrive tale scena. ('Lucia', p. i6 I )

Manzoni, therefore, has appropriated-albeit in a very moderate, reduced form-some of the demands that the imaginary reader has metalinguistically expressed.

In Chapter xxxiv Renzo arrives at the Lazaretto; he finds the woman he loves, states why he opposes the vow of chastity she has taken, avails himself of the help of Father Cristoforo to annul that vow, and finally regains hope, and almost the certainty of being able to marry her. Finally, Valesio observes, 'nella narrazione circola Eros [. . .] o vero sia la gioia' (p. i 69). The same joy unfolds in Renzo's walk in the rain, in the first part of Chapter xxxvir: 'è il trionfo delle emozioni, finalmente'. For Valesio and Spinazzola, these glimpses Manzoni gives of affection in his characters reveal the emergence of something (desire, erotic impulses) that the writer strives to contain, and whose importance he ends up communicating nevertheless.

Manzoni, Valesio also observes, often tries to resist Eros- the demon who jumps 'fuori dal collo stretto di qualche anfora', 'il dio figlio del Caos e della Notte' (p. I68)-and because of this he rarely reaches true greatness (p. I 55). Novels are a vehicle of eros, and one cannot write an excellent novel unless one confronts, within its pages, the ontological challenge that eros poses..$^{\circ}$ Notwithstanding the opposite points of view, this is exactly Nicole's conviction quoted earlier: 'le silence, la patience, la modération, la sagesse, la pauvreté, la pénitence ne sont pas des vertus, dont la représentation puisse divertir les spectateurs'. Manzoni opposed such a thesis with unusual pride, as we have seen in his letters to Degola and Fauriel. He wanted his novel to be about compassion, kindness to neighbour, gentleness, leniency, self-sacrifice. One could wonder if it makes or has made sense to put his intentions, and the results of his project, so resolutely aside.

A first answer comes from Gérard Genette, who, without referring specifically to Manzoni, has dealt at length with all the procedures that we have con-

49 'Renzo avrebbe voluto fermarsi lì, almeno tutto quel giorno, veder le donne allogate, render loro i primi servizi; ma il padre aveva raccomandato a queste di mandarlo subito per la sua strada. Addussero quindi esse e quegli ordini, e cento altre ragioni; che la gente ciarlerebbe che la separazione più ritardata sarebbe più dolorosa, ch'egli potrebbe venir presto a dar nuove e sentirne; tanto che si risolvette di partire. Si concertaron, come poterono, sulla maniera di rivedersi, più presto che fosse possibile. Lucia non nascose le lacrime; Renzo trattenne a stento le sue, e, stringendo forte forte la mano a Agnese, disse con voce soffogata: 'a rivederci', e parti' ( $P S$, pp. I $46-47)$.

'The modern novel, Revel notes, is born with Defoe's Moll Flanders and Prévost's Manon Lescaut; it is 'le moyen de décrire l'amour dans ses rapports avec la sexualité (Pour l'Italie, p. 57). Revel, counters Lugli, seems to forget the other, yet totally French, strand begun with La Princesse de Clèves (Bovary italiane, p. I 38 ). Valesio's position is much more interesting. In a study dedicated to the function and ultimate limits of rhetoric-which to him is the functional organization of discourse, the full language in its fulfilment as discourse (Paolo Valesio, Ascoltare il silenzio (Bologna: Il Mulino, I 986), p. 22)-Valesio claims that verbal discourse and western iconographic tradition can easily represent Eros, but they are arduously pitted against the Otherthan-Eros: 'se la copia verborum è espressa dall'eros, l'agape vive nel silenzio' (p. 334). Manzoni's novel falls outside this classification, and seems to undermine it; this is why, I believe, Valesio notes with surprise Manzoni's effectiveness as a writer, 'la sua demoniaca abilità stilistica' ('Lucia', p. I 45). 
sidered here (and that he defines as transtextual). ${ }^{51}$ These procedures, Genette explains, are necessary because 'l'humanité, qui découvre sans cesse du sens, ne peut toujours inventer de nouvelles formes, et il lui faut bien parfois investir de sens nouveaux des formes anciennes' (p. 453). Manzoni's novel expresses a model of morality; an alternative culture rejecting this model emerged in the twentieth century; its proponents could not always explain their reasons; and reflections on Manzoni's work, at times ferociously hostile to it, have helped to focus on, and to speak of, this new sensitivity. The most pronounced change in the behaviour of Italians between the end of the r 950 os and the beginning of the I 980 s- between Soldati and Valesio-has been filled with contradictions. In so much confusion the reading and reinterpretation of Manzoni's work has helped Italians to define themselves. Manzoni's novel is an extraordinary palimpsest for new exegeses of existence, and has lent itself well to procedures of this nature.

A second answer comes from Paolo Valesio, who-once again in an unrelated, non-Manzonian context-speaks of contrasts that are at the same time 'un'opposizione $e$ un'interpenetrazione delle opposte alternative', and do not, therefore, make for easy choices or synthesis. ${ }^{52}$ Manzoni might have detected one of these contrasts in his digression on love when he tells of having found many scenes of passion in the imaginary manuscript, and of having deleted all of them. He speaks of this fictitious censorship in a provoking manner inviting counter-provocation and a circuitous, though not unusual, type of dialogue. Manzoni could not foresee the nature of the reactions we have studied in the second part of this essay, but he seems to have brought them on, explicitly in the $1823 \mathrm{draft}$, and more cautiously in successive drafts, still presenting his novel as one of the many remakes constituting the history of literature.

${ }^{51}$ Gérard Genette, Palimpsestes: la littérature au second degré (Paris: Seuil, I982), p. 7.

${ }^{52}$ Ascoltare il silenzio, p. I 15. 